\title{
The remarkable solubility-enhancing power of Escherichia coli maltose-binding protein
}

\begin{abstract}
A common problem encountered during the production of recombinant proteins, particularly in bacteria, is their tendency to accumulate in an insoluble and inactive form (i.e., as inclusion bodies). Although sometimes it is possible to convert the aggregated material into native, biologically active protein, this is a time-consuming, costly, and uncertain undertaking. Consequently, a general means of circumventing the formation of inclusion bodies is highly desirable. During the 1990s, it was serendipitously discovered that certain highly soluble proteins have the ability to enhance the solubility of their fusion partners, thereby preventing them from forming insoluble aggregates. In the ensuing years, Escherichia coli maltose-binding protein (MBP) has emerged as one of the most effective solubility enhancers. Moreover, once rendered soluble by fusion to MBP, many proteins are able to fold into their biologically active conformations. This brief review article focuses on our current understanding of what makes MBP such an effective solubility enhancer and how it facilitates the proper folding of its fusion partners.
\end{abstract}

\section{MBP IS AN EXTRAORDINARILY EFFECTIVE SOLUBILITY ENHANCER}

In 1993, McCoy and co-workers reported that the solubility of several mammalian cytokines and growth factors could be improved by fusing them to the highly soluble E. coli protein thioredoxin [1]. However, they did not address the question of whether other highly soluble proteins can also function as solubility enhancers. To investigate this possibility, the solubility of 18 fusion proteins, representing every combination of three highly soluble proteins with six very insoluble ones, was subsequently compared [2]. Remarkably, the results revealed that E. coli maltose-binding protein (MBP) was extraordinarily effective at promoting the solubility of its fusion partners-much more so than either glutathione S-transferase (GST) or thioredoxin (Fig. 1). These experiments demonstrated un-

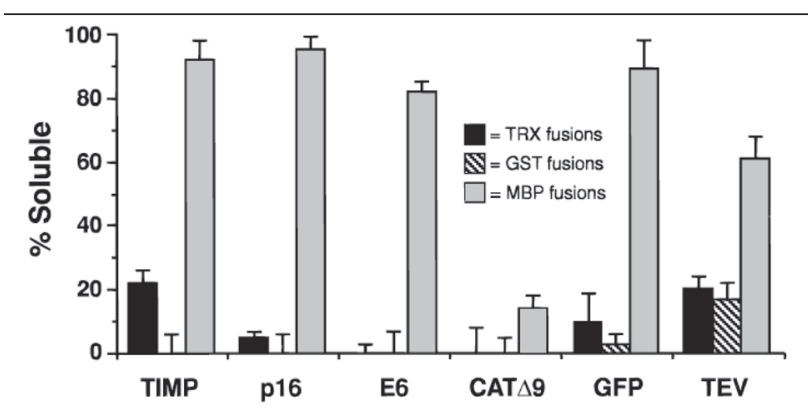

Figure 1. Solubility of TRX, GST, and MBP fusion proteins. The solubility of each fusion protein (\% solubility) was estimated from data obtained by laser scanning densitometery of Coomassie-stained gels. All fusion proteins were expressed at a high level in E. coli.

proteins, appears to be a general property of MBP, because the solubility of all six passengers was markedly improved by fusing them to this solubility enhancer. Importantly, in some cases it could be shown that MBP promoted the proper folding of the attached proteins [2].Twenty years later, many different proteins have been touted as solubility enhancers, but MBP remains one of the most effective and is definitely the most thoroughly studied.

\section{THE CHAPERONE MODEL OF SOLUBILITY ENHANCEMENT}

To explain the extraordinary ability of MBP to enhance the solubility and promote the proper folding of its fusion partners, it was proposed that it can function as a kind of general molecular chaperone in the context of a fusion protein [2]. Specifically, it was envisioned that MBP reversibly binds to folding intermediates of its fusion partners, i.e. passenger proteins, temporarily sequestering

\section{David S. Waugh}

Macromolecular Crystallography Laboratory, Center for Cancer Research, National Cancer Institute at Frederick, Frederick, MD, USA

Macromolecular Crystallography Laboratory, Center for Cancer Research, National Cancer Institute at Frederick, Frederick, MD 21702, USA; email: waughd@mail.nih.gov

Received: May 15, 2016

Accepted: May 17, 2016

Key words: MBP, fusion protein, solubility enhancer, inclusion bodies, aggregation

Abbreviations: GST - glutathione S-transferase; MBP - maltose-binding protein; NusA N-utilization substance A; TRX - thioredoxin

Acknowledgements: This work was supported by the Intramural Research Program of the NIH, National Cancer Institute, Center for Cancer Research. 
them in a conformation that prevents their self-association and aggregation. Over time, iterative cycles of binding and release could lead to the evolution of properly folded fusion proteins. According to this model, the folding of passenger proteins, when it occurs at all, is spontaneous and MBP serves only to inhibit the kinetically competing pathway of aggregation, and hence MBP and other solubility enhancers play a passive role in the folding process. This hypothesis was supported by the observation that the folding of ten different aggregation-prone proteins, as assessed by their degree of solubility after tag removal, was very similar when fused to MBP or NusA, another highly effective solubility enhancer [3]. Obtaining definitive proof for or against this mechanism has proven to be quite a challenge, however.

\section{MUTATIONS THAT INFLUENCE THE ABILITY OF MBP TO ENHANCE THE SOLUBILITY OF ITS FUSION PARTNERS}

It seems reasonable to envision that hydrophobic interactions would play a significant role in the association between fusion partners, if this occurs, since hydrophobicity is thought to be a distinguishing characteristic of incompletely folded proteins and the key feature that targets them for recognition by authentic chaperones [4]. There are several large clusters of hydrophobic residues on the surface of MBP, but the most enticing candidate for a protein interaction site is the deep, hydrophobic cleft that the protein uses to bind maltodextrins. Because this feature is not present in either GST or thioredoxin, this would provide a rationale for why $\mathrm{MBP}$ is a much more effective solubilizing agent than these proteins. Moreover, the cleft is obviously large enough to accommodate a polypeptide ligand, and the inherent flexibility of the structure in solution [5] could enable the protein to adopt a variety of conformations in response to different peptides. Additionally, if passenger proteins occasionally occupy the ligand-binding cleft of MBP, this would explain why some MBP fusion proteins do not bind efficiently to amylose resin [6].

If this hypothesis is correct, then amino acid substitutions in the ligand-binding cleft of MBP might be expected to influence the solubility of fusion proteins, causing them to accumulate in an insoluble form by destabilizing the physical association between MBP and folding intermediates of its fusion partners that normally prevents them from aggregating. To test this hypothesis, six residues were targeted for site-directed mutagenesis: W62, A63, Y155, W230, W232, and W340 (Fig. 2, top) [7]. Each of these side chains was replaced with the bulky, negatively charged glutamate substituent. In the unfused state, the yield and solubility of all six mutants were indistinguishable from wild-type MBP. The impact of the mutations was then assessed in the context of several fusion proteins, using three aggregation-prone passenger proteins: the tumor suppressor p16, the human papilloma virus E6 oncoprotein, and green fluorescent protein (GFP). Almost all of the mutant fusion proteins were just as soluble as their wild-type counterparts. Only the W232E mutants, and to a lesser extent the W230E mutants, exhibited a significant reduction in solubility. The phenotype of the W232E mutation was quite striking, however, because it had a dramatic effect on the solubility of all three fusion proteins. When

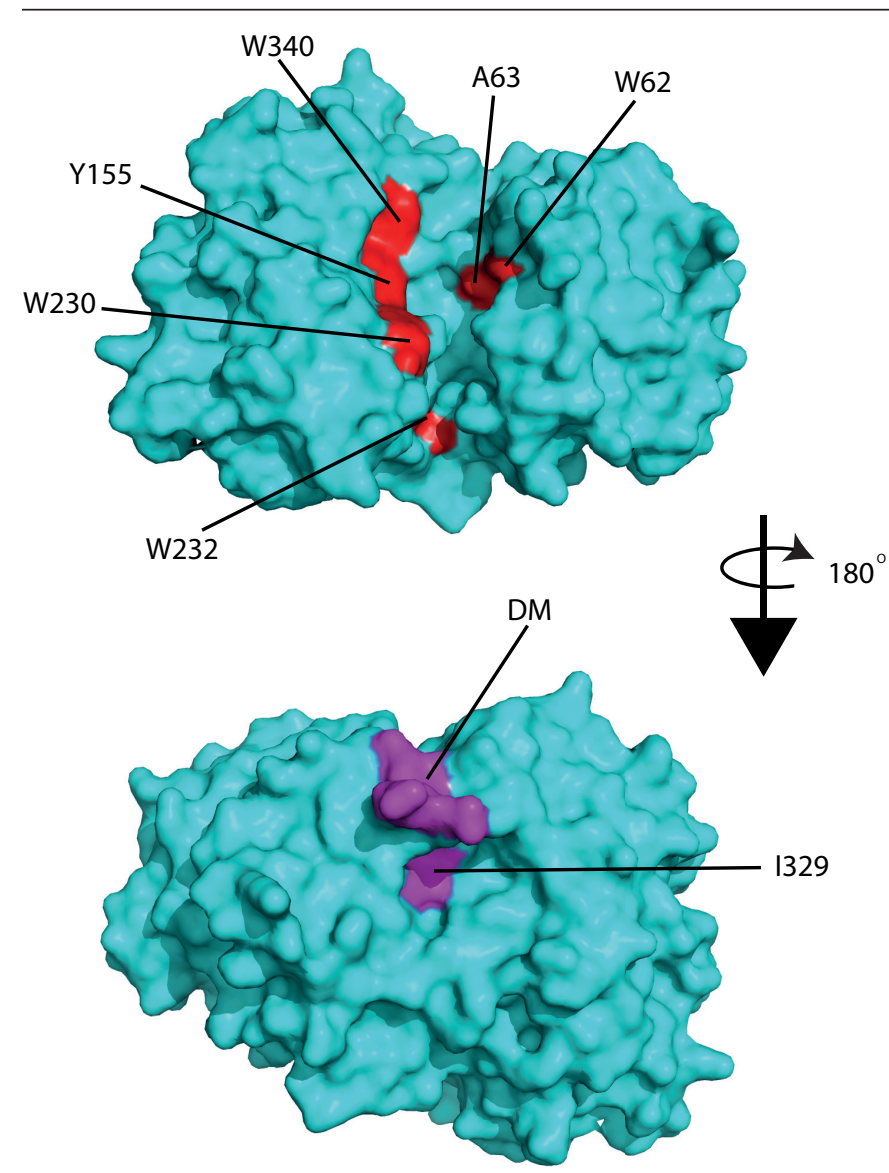

Figure 2. Space-filling representation of the unliganded E. coli MBP crystal structure (PDB code 1OMP). Amino acids that were altered by site-directed mutagenesis are highlighted.

glutamate substitutions were made at two solvent-exposed positions adjacent to W232 but farther from the cleft, Y242 and I317, neither mutation had any appreciable effect on the yield or solubility of MBP in its unfused state but both mutations dramatically reduced the solubility of the MBP-p16, MBP-E6, and MBP-GFP fusion proteins. Although they are widely dispersed in the sequence and reside in distinct elements of the secondary structure, these three side chains form a nearly contiguous patch on the surface of the folded protein. The existence of a solvent-exposed "hotspot" is consistent with the interaction-site hypothesis. Moreover, if this interpretation is correct, it can also be concluded that MBP uses the same site to interact with different passenger proteins. On the other hand, equilibrium denaturation experiments monitored by circular dichroism revealed that the three mutants with a significant solubility reducing phenotype are less stable than wild-type MBP, raising the possibility that the solubility defects may arise from a change in the global stability of MBP rather than from the disruption of a general protein interaction site [7].

Several groups have described mutations in MBP that increase its affinity for maltose [8-10]. Using a variety of experimental techniques, these mutations were shown to exert their effect by altering the equilibrium between the "open" and "closed" conformations of MBP so as to favor the latter. In the open conformation, the ligand-binding cleft of MBP is exposed to solvent, whereas the closed conformation re- 
sembles that of the ligand-bound protein in which the cleft is largely buried. Interestingly, two of these mutant MBPs, the so-called "DM mutant" (a combination of M321A, Q325A and a deletion of residues 172-176) and I329W (Fig. 2 , bottom), were found to have profoundly impaired solubility-enhancing ability, suggesting that the solubilizing properties of MBP are mediated by its open conformation [11]. Moreover, these mutations do not appreciably alter the global stability of MBP. This study also found that double substitutions of hydrophobic residues in the ligand-binding cleft (W62E/Y155E and W230E/W340E) also reduced the solubility of fusion proteins, although their global stability was not investigated.

\section{THE ORDER OF DOMAINS IN MBP FUSION PROTEINS INFLUENCES THEIR SOLUBILITY}

The chaperone model posits that partially or incorrectly folded passenger proteins bind transiently to the surface of $\mathrm{MBP}$, and that this intramolecular interaction prevents the fusion proteins from forming insoluble aggregates. A corollary of this hypothesis is that MBP needs to fold first, before its fusion partner does. If so, then one would predict that MBP should be a more effective solubility enhancer when it is fused to the $\mathrm{N}$ terminus of the passenger protein (i.e., when it is translated first) than when it is fused to its $C$ terminus. Previous attempts to address this question yielded conflicting results $[12,13]$ and were either limited in scope or technically unsound. More recently, a rigorous test of this prediction was conducted using GFP, DHFR, DUSP14 and TEV protease as passenger proteins [14]. The initial results were confounded by the fact that when the variable proteins were the N-terminal fusion partners, the yield of fusion proteins fluctuated widely, probably as a consequence of differing translation initiation efficiency. To overcome this problem, tripartite constructs were assembled in which all fusion proteins included an identical N-terminal polyhistidine tag (e.g., His 6 -MBP-GFP and His -GFP-MBP). Using this approach, it could be shown that MBP is indeed a substantially more effective solubility enhancer when it is fused to the $\mathrm{N}$ terminus of a passenger protein rather than to its
$\mathrm{C}$ terminus. Additionally, greater yields of fusion proteins were obtained when MBP was the N-terminal fusion partner.

\section{MBPS FROM DIVERSE MICROORGANISMS ALSO FUNCTION AS SOLUBILITY ENHANCERS}

Another way to gain some insight into the properties of E. coli MBP (EcoMBP) that make it such an unusually effective solubilizing agent would be to compare the ability of orthologous proteins to promote solubility; perhaps some patterns would emerge that would reveal clues about the mechanism of the solubilizing effect. Moreover, because there is no a priori reason to believe that nature optimized EcoMBP for this task, it is possible that MBPs from other organisms might be even better solubilizing agents. To investigate this possibility, five orthologs exhibiting varying degrees of amino acid sequence identity with EcoMBP (Yersinia pestis (Ype), 85\%; Vibrio cholerae (Vch), 68\%; Thermotoga maritima (Tma), 35\%; Thermococcus litoralis (Tli), $30 \%$; and Pyrococcus furiosus (Pfu), 27\%) were compared to evaluate their ability to promote the solubility of eight different aggregation-prone proteins in E. coli [15]. The passenger proteins used for these experiments were p16, GFP, E6, chloramphenicol acetyltransferase-Dh (CATD9), bovine rhodanese, Photinus pyralis luciferase, murine glyceraldehyde-3-phosphate dehydrogenase (G3PDH), and human dihydrofolate reductase (DHFR). These proteins represent a wide range of origins, sizes, physicochemical properties and functions. Rhodanese, luciferase, G3PDH and DHFR are commonly used as model substrates for the molecular chaperone GroEL [16-22].

To begin with, each MBP was overproduced in E. coli to assess its yield and solubility in the unfused state. The yields of the Ype, Vch, Tma, Tli and Pfu MBPs were very similar to that of EcoMBP, easily comprising the majority of the intracellular protein content, and all of them were highly soluble. TliMBP does not bind to amylose resin [23], but all of the other MBPs were quantitatively retained on an amylose column, indicating that they were properly folded.


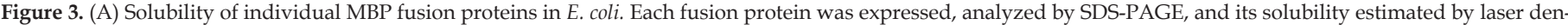

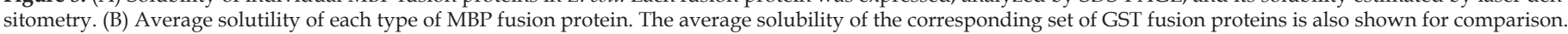


Next, the six MBPs were fused to the eight aggregation-prone passenger proteins and the solubility of the 48 fusion proteins was compared. The results indicated that while all of the MBPs were capable of enhancing the solubility of their fusion partners, some were consistently more effective than others (Fig. 3). The best solubilizing agent was $P f u \mathrm{MBP}$, the most distant relative of EcoMBP, whereas the closest relative of EcoMBP, YpeMBP, was the least effective overall. There was no correlation between the efficacy of solubility enhancement and thermostability or isoelectric point. For the most part, those passenger proteins that were solubilized most readily by YpeMBP (GFP, p16 and E6) tended also to be solubilized most efficiently by the other MBPs, suggesting that the underlying mechanism of the solubilizing effect is likely to be similar for all six MBPs. The two passenger proteins that were consistently most difficult to solubilize, CATD9 and luciferase, exhibited a dramatic increase in solubility when they were fused to PfuMBP. On average $P f u \mathrm{MBP}$ was about $50 \%$ more effective than EcoMBP and almost twice as effective as YpeMBP at promoting the solubility of the eight passenger proteins employed in this study. The average solubility of the corresponding GST fusion proteins was negligible by comparison. It is intriguing that although relatively few proteins appear to be generally effective solubilizing agents, this seems to be a common property of even distantly related maltodextrin-binding proteins.

\section{INSIGHTS FROM REFOLDING EXPERIMENTS}

Refolding experiments have also been performed in an effort to probe the mechanism of solubility enhancement by MBP [24]. Five passenger proteins with measurable activities that can be used to monitor their folding were utilized in these experiments: G3PDH, DHFR, GFP, human dual specificity phosphatase 14 (DUSP14) and TEV protease. These passengers were fused to three different $\mathrm{N}$-terminal tags: $\mathrm{His}_{6}{ }^{\prime} \mathrm{His}_{6}-\mathrm{MBP}$ and $\mathrm{His}_{6}-\mathrm{GST}$. The 15 fusion proteins were purified under denaturing conditions by immobilized metal affinity chromatography and then refolded by rapid dilution. The results of the refolding experiments were unequivocal: in all cases more soluble MBP fusion protein was recovered than soluble GST- or His-tagged protein after refolding and in most instances the difference was considerable. Hence, it was possible to reproduce the solubilizing activity of MBP in a simple in vitro refolding system, indicating that no additional factors are required to mediate this effect.

To determine whether or not the passenger proteins were properly folded, both the soluble fusion proteins and their TEV protease digestion products were assayed for enzymatic activity (or fluorescence in the case of GFP). Little or no activity was detected for the G3PDH and DHFR fusion proteins or the cleaved passengers, but the GFP, TEV protease and DUSP fusion proteins were quite active. Yet when the MBP fusion proteins were purified under native (non-denaturing) conditions, substantial activity was detected for all of the passenger proteins. Hence, the ability of MBP to promote the solubility of its fusion partners in vitro sometimes but not always results in their proper folding.

These findings have implications for the mechanism by which MBP influences the folding of its fusion partners. Folding evidently does not always occur spontaneously, as previously thought, but instead in some cases requires other factor(s) in vivo that are absent in vitro. These additional factors could be bacterial chaperones. Indeed, one published study implicated the chaperonin GroES/GroEL in the folding of an MBP-UCP1 fusion protein [25]. Yet MBP itself is rather large (ca. $42 \mathrm{kDa}$ ), and therefore many fusion proteins would be too big to fit inside the "Anfinsen cage" formed by the chaperonin, which was originally thought not to be able to accommodate proteins larger than $\sim 60 \mathrm{kDa}$ [26]. However, more recent studies have uncovered a so-called "trans-mechanism" $[27,28]$ that enables the chaperonin to interact productively with larger client proteins.

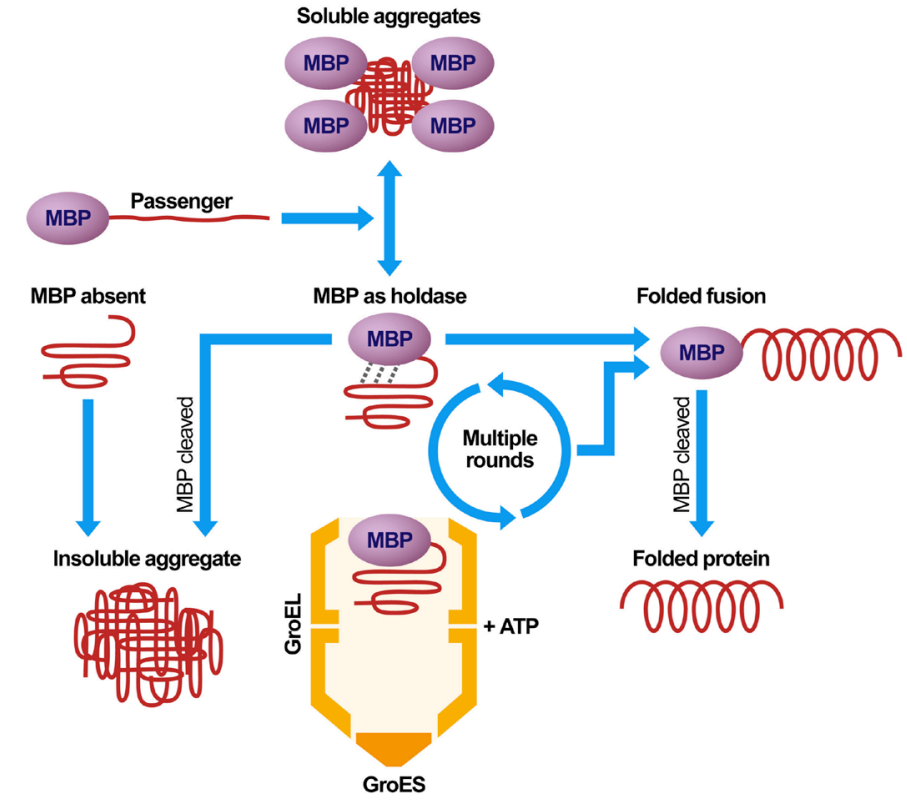

Figure 4. A model illustrating the roles that MBP plays in the production of recombinant proteins. See text for discussion.
To investigate the role of $E$. coli chaperones in the folding of MBP fusion proteins, the effect of dnaJ, dnaK or tig (trigger factor) knockout mutations on the recovery of active MBP-DHFR or MBP-G3PDH was assessed [24]. None of these mutations reduced the activity of either fusion protein. The genes encoding GroEL and GroES are essential for viability, so a similar knockout experiment could not be performed to assess their role in the folding of these fusion proteins. However, Weissman and colleagues utilized directed evolution to identify a mutant GroEL/GroES that is substantially more effective than wild-type GroEL/GroES at promoting the folding of GFP [29]. This mutant chaperonin was used to ask whether or not GroEL/GroES is capable of interacting with MBP fusion proteins by examining its impact on the fluorescence emitted by MBP-GFP [24]. The fluorescence was substantially greater when the mutant GroEL/GroES was coexpressed with MBP-GFP (69 $\mathrm{kDa}$ ) than when 
the wild-type chaperonin was coexpressed at an equal level. Similar results were obtained with a NusA-GFP fusion protein $(81 \mathrm{kDa})$. These results unequivocally demonstrate that the GroEL/GroES chaperonin is capable of interacting productively with proteins at least as large as $81 \mathrm{kDa}$. Therefore, it is feasible that they may also mediate the folding of MBP-DHFR (67 kDa) and MBP-G3PDH (79 kDa) in E. coli. Moreover, it has been shown that the addition of purified GroEL/GroES and ATP stimulates the refolding of G3PDH and DHFR in vitro and that overexpression of GroEL/GroES improves the solubility of several MBP fusion proteins in $E$. coli [24].

\section{A BIFURCATED PATHWAY FOR THE FOLDING OF MBP FUSION PROTEINS}

The discovery that molecular chaperones participate in the folding of some MBP fusion proteins necessitated a revision of the original intramolecular "chaperone" model (Fig. 4). A protein that normally accumulates in the form of insoluble aggregates when expressed in an unfused state in E. coli (MBP absent) is prevented from doing so when fused to MBP. Exactly how MBP promotes the solubility of its fusion partners is still uncertain but this may involve a transient physical interaction between a folded MBP moiety and an incompletely folded passenger protein (MBP as holdase). The incompletely folded passenger protein may engage in multiple rounds of binding to and release from MBP. Some passenger proteins reach their native conformation by spontaneous folding after one or more cycles, while in other cases MBP facilitates the interaction between an incompletely folded passenger protein and one or more endogenous chaperones, most likely the GroESL chaperonin (Folded fusion). In both cases, MBP serves primarily as a "holdase", keeping the incompletely folded passenger protein from forming insoluble aggregates until either spontaneous or chaperone-mediated folding can occur. A third class of passenger proteins is unable to fold via either of these pathways and exists perpetually in an incompletely folded state, either as an intramolecular or intermolecular (i.e., micelle-like) aggregate (Soluble aggregates). These passenger proteins typically precipitate after they are cleaved from MBP by a site-specific protease (Insoluble aggregates).

\section{CONCLUDING REMARKS AND FUTURE PERSPECTIVES}

At this point, we have a relatively good understanding of how folding occurs once aggregation is prevented by fusing a protein to $\mathrm{MBP}$, yet we still lack a firm understanding of what qualities (other than high solubility in E. coli) enable certain proteins like MBP to function as highly effective solubility enhancers. Unfortunately, despite abundant evidence to the contrary, the notion persists that virtually any highly soluble protein can function as a solubility enhancer in the context of a fusion protein. Indeed, even today it is difficult to find a review article on the subject that doesn't extoll the solubility-enhancing properties of GST despite the fact that numerous studies have shown it to be a very poor solubility enhancer $[2,13,15,30]$. This erroneous notion needs to be dispelled. In the case of MBP, although there is some evidence to suggest that its ligand-binding cleft may contribute to its remarkable solubility enhancing capability, not all ex- perimental observations are consistent with this model. For example, no difference in the yield of soluble protein was observed when refolding experiments were performed in the presence and absence of maltose [24]. Moreover, NusA, another highly effective solubility enhancer, lacks a similar ligand-binding cleft. One common feature of MBP and NusA is that both proteins have evolved to interact with a variety of other proteins in the cell and have a number of hydrophobic patches on their surfaces that are utilized to form multi-protein complexes. It is possible that passenger proteins could interact transiently with more than one hydrophobic patch on the surface of these solubility enhancers to avoid self-association and aggregation. Further work is needed to explore this possibility. For those proteins that fail to fold properly after being rendered soluble by fusing them to MBP, co-expression with eukaryotic chaperones may be beneficial.

\section{REFERENCES}

1. LaVallie ER, DiBlasio EA, Kovacic S, Grant KL, Schendel PF, McCoy JM (1993) A thioredoxin gene fusion expression system that circumvents inclusion body formation in the E. coli cytoplasm. BioTechnology 11: 187-193

2. Kapust RB, Waugh DS (1999) Escherichia coli maltose-binding protein is uncommonly effective at promoting the solubility of polypeptides to which it is fused. Protein Sci 8: 1668-1674

3. Nallamsetty S, Waugh DS (2006) Solubility-enhancing proteins MBP and NusA play a passive role in the folding of their fusion partners. Protein Expr Purif 45: 175-182

4. Bhandari V, Houry WA (2015) Substrate interaction networks of the Escherichia coli chaperones: Trigger factor, DnaK and GroEL. Adv Exp Med Biol 883: 271-294

5. Marvin JS, Corcoran EE, Hattangadi NA, Zhang JV, Gere SA, Hellinga HW (1997) The rational design of allosteric interactions in a monomeric protein and its applications to the construction of biosensors. Proc Natl Acad Sci USA 94: 4366-4371

6. Routzahn K, Waugh DS (2002) Differential effects of supplementary affinity tags on the solubility of MBP fusion proteins. J Struct Funct Genomics 2: 83-92

7. Fox JD, Waugh DS (2001) Single amino acid substitutions on the surface of Escherichia coli maltose-binding protein can have a profound impact on the solubility of fusion proteins. Protein Sci 10: 622-630

8. Telmer PG, Shilton BH (2003) Insights into the conformational equilibria of maltose-binding protein by analysis of high affinity mutants. J Biol Chem 278: 34555-3456

9. 7Marvin JS, Hellinga HW (2001) Manipulation of ligand binding affinity by exploitation of conformational coupling. Nat Struct Biol 8: 795-798.

10. Walker IH, Hsieh PC, Riggs PD (2010) Mutations in maltose-binding protein that alter affinity and solubility properties. Appl Microbiol Biotechnol 88: 187-197

11. Nallamsetty S, Waugh DS (2007) Mutations that alter the equilibrium between open and closed conformations of Escherichia coli maltose-binding protein impede its ability to enhance the solubility of passenger proteins. Biochem Biophys Res Commun 364: 639-644

12. Sachdev D, Chirgwin JM (1998) Order of fusions between bacterial and mammalian proteins can determine solubility in Escherichia coli. Biochem Biophys Res Commun 244: 933-937

13. Dyson MR, Shadbolt SP, Vincent KJ, Perera RL, McCafferty J (2004) Production of soluble mammalian proteins in Escherichia coli: identification of protein features that correlate with successful expression. BMC Biotechnol 4: 32

14. Raran-Kurussi S, Keefe K, Waugh DS (2015) Positional effects of fusion partners on the yield and solubility of MBP fusion proteins. Protein Expr Purif 110: 159-164 
15. Fox JD, Routzahn KM, Bucher MH, Waugh DS (2003) Maltodextrin-binding proteins from diverse bacteria and archaea are potent solubility enhancers. FEBS Lett 537: 53-57

16. Weber F, Keppel F, Georgopoulos C, Heyer-Hartl MK, Hartl, F.U. (1998) The oligomeric structure of GroEL/GroES is required for biologically significant chaperonin function in protein folding. Nat Struct Biol 5: 977-985

17. Chatellier J, Hill F, Lund PA, Fersht AR (1998) In vivo activities of GroEL minichaperones. Proc Natl Acad Sci USA 95: 9861-9866

18. Altamirano MM, Golbik R, Zahn R, Buckle AM, Fersht, AR (1997) Refolding chromatography with immobilized mini-chaperones. Proc Natl Acad Sci USA 94: 3576-3578

19. Ewalt KL, Hendrick JP, Houry WA, Hartl FU (1997) In vivo observation of polypeptide flux through the bacterial chaperonin system. Cell 90: 491-500

20. Zahn R, Buckle AM, Perrett S, Johnson CM, Corrales FJ, Golbik R, Fersht AR (1996) Chaperone activity and structure of monomeric polypeptide binding domains of GroEL. Proc Natl Acad Sci USA 93: 15024-15029

21. Wang JD, Michelitsch MD, Weissman JS (1998) GroEL-GroES-mediated protein folding requires an intact central cavity. Proc Natl Acad Sci USA 95: 12163-12168

22. Zhang S, Li J, Wang CC (2001) GroEL-assisted dehydrogenase folding mediated by coenzyme is ATP-independent. Biochem Biophys Res Commun 285: 277-282
23. Diez J, Diederichs K, Greller G, Horlacher R, Boos W, Welte, W (2001) The crystal structure of a liganded trehalose/maltose-binding protein from the hyperthermophilic archaeon Thermococcus litoralis at $1.5 \AA$ resolution. J Mol Biol 305: 905-915

24. Raran-Kurussi S, Waugh DS (2012) The ability to enhance the solubility of its fusion partners is an intrinsic property of maltose-binding protein but their folding is either spontaneous or chaperone-mediated. PLoS One 7: e49589

25. Douette P, Navet R, Gerkens P, Galleni M, Levy D, Sluse FE (2005) Escherichia coli fusion carrier proteins act as solubilizing agents for recombinant uncoupling protein 1 through interactions with GroEL. Biochem Biophys Res Commun 333: 686-693

26. Ellis RJ (2006) Protein folding: inside the cage. Nature 442: 360-362

27. Inbar E, Horovitz A (1997) GroES promotes the T to R transition of the GroEL ring distal to GroES in the GroEL-GroES complex. Biochemistry 36: 12276-12281

28. Chaudhuri TK, Farr GW, Fenton WA, Rospert S, Horwich AL (2001) GroEL/GroES-mediated folding of a protein too large to be encapsulated. Cell 107: 235-246

29. Wang JD, Herman C, Tipton KA, Gross CA, Weissman JS (2002) Directed evolution of substrate-optimized GroEL/S chaperonins. Cell 111: 1027-1039

30. Hammarstrom M, Hellgren N, van Den Berg S, Berglund H, Hard, T (2002) Rapid screening for improved solubility of small human proteins produced as fusion proteins in Escherichia coli. Protein Sci 11: 313321

\section{Niezwykła zdolność MBP Escherichia coli do zwiększania rozpuszczalności innych białek}

\section{David S. Waugh}

Macromolecular Crystallography Laboratory, Center for Cancer Research, National Cancer Institute at Frederick, Frederick, MD, USA e-mail: waughd@mail.nih.gov

Słowa kluczowe: MBP, białko fuzyjne, czynnik zwiększający rozpuszczalność, ciała inkluzyjne, agregacja

\section{STRESZCZENIE}

Częsty problem spotykany podczas produkcji białek rekombinowanych, zwłaszcza w bakteriach, to skłonność tych białek do akumulowania się w nierozpuszczalnej i nieaktywnej formie (tzw. ciał inkluzyjnych). Zdarza się, że możliwe jest przywrócenie tym agregatom formy natywnego, biologicznie aktywnego białka, jednak jest to proces czasochłonny, kosztowny i nieprzewidywalny. Z tego względu konieczne jest opracowywanie metod zapobiegania tworzeniu się ciał inkluzyjnych. W latach 90. przypadkowo odkryto zdolność niektórych wysoce rozpuszczalnych białek do zwiększania rozpuszczalności białek tworzących z nimi białko fuzyjne. Ta właściwość uniemożliwia powstawanie nierozpuszczalnych agregatów. Podczas późniejszych badań zidentyfikowano białko wiążące maltozę (MBP) Escherichia coli jako cechujące się bardzo dużą zdolnością zwiększania rozpuszczalności innych białek. Co więcej, wiele białek po zwiększeniu ich rozpuszczalności za pomocą fuzji z MBP, zachowuje konformację zapewniającą biologiczną aktywność. W niniejszym krótkim artykule przeglądowym przedstawiono aktualny stan wiedzy w zakresie zwiększania rozpuszczalności innych białek w wyniku fuzji z MBP, a jednocześnie zachowywania prawidłowego fałdowania tych białek. 